\title{
Evaluation of dyslipidemia in type 2 diabetes mellitus
}

\author{
Devendra Pratap Singh Rajput ${ }^{1}$, Javed Yusuf Shah'2, Priti Singh ${ }^{3}$, Shyransh Jain ${ }^{4}$ \\ ${ }^{1}$ Associate Professor, Department of Medicine, L.N.Medical College, Bhopal, ${ }^{2}$ Assistant Professor, Department of Medicine, L.N.Medical College, \\ Bhopal, ${ }^{3}$ Assistant Professor, Department of Opthalmology, L. N. Medical College, Bhopal, ${ }^{4}$ M.B.B.S. Student, L.N.Medical College, Bhopal
}

Back ground: In type 2 diabetes mellitus lipid abnormalities are almost the rule. Dyslipidemia has been noted to play an integral role in the pathogenesis and progression of micro and macrovascular complications in diabetes mellitus patients. The complications exemplified by renal, cerebrovascular and cardiovascular disease cause the most morbidity and mortality in this group of patients. Aims and Objective: This study is aimed at understanding the pattern of dyslipidemia among type 2 diabetic patients. Material and method: During two month study period, total 100 patients with diabetes mellitus were evaluated for dyslipidemia. Plasma glucose was estimated by GOD-POD method and Lipid profile by photometry method. Lipid profile was evaluated by investigating the subjects for total cholesterol, serum triglyceride, high density lipoprotein, low density lipoprotein and very low density lipoprotein. In statistical analysis data were analyzed by using various statistical methods like percentage, proportions and tables by using epi info software. Results: out of 100 patients $72(72 \%)$ were males and $28(28 \%)$ were females. The mean fasting blood sugar of total patients with type 2 diabetes mellitus was $158.35 \mathrm{mg} / \mathrm{dl}$. in male diabetics, fasting blood sugar level with diabetes mellitus was $157.56 \mathrm{mg} / \mathrm{dl}$ and in female diabetics it was $159.14 \mathrm{mg} / \mathrm{dl}$. The pattern of dyslipidemia in our study showed significantly higher levels of serum cholesterol, serum triglyceride, LDL-C in both male and female diabetics and lower levels of HDL-C in female diabetics. There was no significant difference in lipid profile pattern in male and female diabetic patients except lower levels of HDL-C in female diabetic patients. Conclusion: This study showed that dyslipidemia is highly prevalent among type 2 diabetic patients.

Key words: Type 2 Diabetes mellitus, Dyslipidemia

\section{INTRODUCTION}

Diabetes mellitus (DM) is a group of metabolic diseases characterized by increased blood glucose level resulting from defects in insulin secretion, insulin action, or both. ${ }^{1}$ The incidence of diabetes is growing at dramatic rates around the world. ${ }^{2}$ Diabetes mellitus (DM) is a major public health challenge in the century with over 190 million worldwide suffering from the disease now, and with a potential to have 324 million by 2025 . The prevalence and incidence of type-2 diabetes varies among ethnic groups, such as higher rates in Asians than in western population even under the condition of similar body mass index. ${ }^{3}$ Diabetes mellitus is a common endocrine disorders rising in India and has reached approximately $20 \%$ in urban populations and approximately $10 \%$ in rural populations. ${ }^{4} \mathrm{DM}$ is a metabolic pathology characterized by raised circulatory glucose, accompanied by diminished cellular glucose uptake and metabolism, as well as altered lipids and protein metabolism. ${ }^{5}$ Hyperglycemia and atherosclerosis are related in type-2 diabetes. ${ }^{6}$ Persistent hyperglycemia causes glycosylation of all proteins, especially collagen cross linking and matrix proteins of arterial wall. This eventually causes endothelial cell dysfunction, contributing further to atherosclerosis. The prevalence of dyslipidemia in diabetes mellitus is $95 \%$. The impact of coronary heart disease in industrialized countries as the leading cause of death in men and women is well documented ${ }^{8,9}$ and in the developing world it is now becoming an increasing cause of death..$^{10}$ Dyslipidemia occurs as a result of metabolic derangement which in type- 2 diabetic patients is basically due to insulin resistance leading to defect in lipid handling. Insulin resistance, relative insulin deficiency, 
and obesity are associated with hypertriglyceridemia, low serum HDL cholesterol concentrations, and occasionally high serum low density lipoprotein (LDL) cholesterol and lipoprotein (a) values. ${ }^{11,12}$ Patients with diabetic dyslipidemia have lipid particles that are more atherogenic than in general population and even are at slightly increased risk of cardiovascular morbidity and mortality. ${ }^{13}$ Insulin resistance, an important factor in type 2 diabetes mellitus, leads to excess liberation of free fatty acids from adipose tissue. ${ }^{14,15}$ The hepatic metabolism of lipoproteins to a large extent is controlled by insulin and this has implications for the lipid profiles and increases the risk of developing ischemic heart disease. ${ }^{16}$ Treatment of dyslipidemia helps in prevention as well as control of other associated co-morbidities. The ability to diagnose and treat dyslipidemia in these patients may greatly enhance the quality of life. Hence the need to detect such cases where dyslipidemia contributes to morbidity and mortality and where it is the cause for poor control of the associated conditions.

Therefore in present Study the prevalence of Dyslipidemia in Type 2 diabetes mellitus patients and the pattern of Dyslipidemia in type 2 diabetic patients is studied.

\section{MATERIALS AND METHODS}

The present cross sectional study entitled "Evaluation of dyslipidemia in type 2 diabetic patients" was carried out at department of medicine, L.N. Medical college and associated J.K. Hospital \& Research Centre, Bhopal (M.P.) during $27 / 07 / 13$ to $26 / 01 / 14$. The study was carried out on 100 diabetic patients attending the medicine department during the study period. Informed consent was obtained from all the patients.

\section{Inclusion criteria}

1. Known case of type 2 Diabetes mellitus

2. Recently diagnosed case of type 2 Diabetes mellitus

The diagnosis of Diabetes Mellitus was based on the American Diabetes Association criteria for type 2 Diabetes Mellitus:

1 Fasting plasma glucose level higher than $126 \mathrm{mg} / \mathrm{dl}$ or

2. Plasma Glucose level exceeding $200 \mathrm{mg} / \mathrm{dl}$ at 2 hours in the $75 \mathrm{~g}$ oral glucose tolerance test or

3. Symptoms of Diabetes and Random Plasma Glucose $>200 \mathrm{mg} / \mathrm{dl}$ or

4. $\mathrm{HbA} 1 \mathrm{C}>6.5 \%$.

\section{Exclusion criteria}

1. Patient on insulin therapy

2. Patient on lipid lowering drugs

3. Diabetic patients with chronic renal failure

4. Nephrotic syndrome
5. Hypothyroidism

6. Family history of dyslipidemia

7. Patient on drugs like- betablocker, thiazides and diuretic.

8. Drugs that cause dyslipidemia

9. Obesity.

Instruments used for assessment

SUGAR- GOD-POD method[semi autoanalyser (BTS-350) fully autoanalyser (BIOSYSTEM A-25) Lipid profile by photometry method-

CHOD-chod pod method

HCHO-enzyme selective protection method LDL-homogenous enzymatic colorimetric assay TRIG-enzymatic colorimetric method VLDL-derived from serum triglyceride values.

\section{Laboratory Data}

Venous blood sample were withdrawn after fasting for 8 Hours and assay for Lipid profile.

Normal values for lipid profiles were taken as-

Total cholesterol 140-200 mg/dl

Triglyceride up to $150 \mathrm{mg} / \mathrm{dl}$

High density lipoprotein $>35 \mathrm{mg} / \mathrm{dl}$ (Male) \& $>45 \mathrm{mg} / \mathrm{dl}$ (Female)

Low density lipoprotein $<130 \mathrm{mg} / \mathrm{dl}$

Very low density lipoprotein- up to $30 \mathrm{mg} / \mathrm{dl}$.

\section{Statistical analysis}

After collection data were analyzed by using various required statistical methods like percentage, proportions and tables by using epi info software. Chi square test of significant was used to see the statistical significant of difference between males and females. P value of $<0.05$ was considered significant for the purpose of study.

\section{OBSERVATION \& RESULTS}

The study population comprised of 100 patients of type 2 diabetics with a 72 males and 28 females, as shown in table 1.

In total type 2 diabetic patients mean fasting blood sugar was found to be $158.35 \mathrm{mg} / \mathrm{dl}$ with ranging from $101 \mathrm{mg} / \mathrm{dl}$ to $345 \mathrm{mg} / \mathrm{dl}$. In male type 2 diabetics mean fasting blood sugar was $157.56 \mathrm{mg} / \mathrm{dl}$ (range 120-293 mg/dl) and in female type 2 diabetics mean fasting blood sugar was $159.14 \mathrm{mg} / \mathrm{dl}$ (range $101-345 \mathrm{mg} / \mathrm{dl}$ ) as shown in table 2.

In type 2 diabetic patients mean Serum cholesterol was $202.4 \mathrm{mg} / \mathrm{dl}$, it was $201.6 \mathrm{mg} / \mathrm{dl}$ in males and $203.2 \mathrm{mg} / \mathrm{dl}$ in female patients. Mean triglycerides level was $152.02 \mathrm{mg} / \mathrm{dl}$ in total diabetics, $137.45 \mathrm{mg} / \mathrm{dl}$ in male patients and $166.60 \mathrm{mg} / \mathrm{dl}$ in female patients. Mean HDL-C level was $42.86 \mathrm{mg} / \mathrm{dl}$ in total diabetic patients, 43.40 in 


\begin{tabular}{lcc}
\multicolumn{3}{l}{ Table 1: Sex distribution of type 2 diabetic patients } \\
\hline Total subject & Male patients & Female patients \\
\hline 100 & 72 & 28 \\
\hline
\end{tabular}

\begin{tabular}{lccc}
$\begin{array}{l}\text { Table 2: Fasting blood sugar levels in type } 2 \\
\text { diabetic patients }\end{array}$ & $\begin{array}{c}\text { Total } \\
\text { patients }\end{array}$ & $\begin{array}{c}\text { Male } \\
\text { patients }\end{array}$ & $\begin{array}{c}\text { Female } \\
\text { patients }\end{array}$ \\
\hline Blood sugar & 158.35 & 157.56 & 159.14 \\
& $101-345$ & $120-293$ & $101-345$ \\
\hline Mean blood sugar $(\mathrm{mg} / \mathrm{dl})$ & & & \\
Range $(\mathrm{mg} / \mathrm{dl})$ &
\end{tabular}

male patients and $42.32 \mathrm{mg} / \mathrm{dl}$ in female diabetic patients. Mean LDL-C level was $127.06 \mathrm{mg} / \mathrm{dl}$ in total patients, $127.30 \mathrm{mg} / \mathrm{dl}$ in male patients and $126.64 \mathrm{mg} / \mathrm{dl}$ in female diabetic patients as shown in table 3 .

In type 2 diabetic patients mean triglycerides was found to be $152.02 \mathrm{mg} / \mathrm{dl}$ in total diabetic patients. Serum triglycerides $<150 \mathrm{mg} / \mathrm{dl}$ was found to be in total $60(60 \%)$ diabetic patients, $44(61.111 \%)$ male diabetics and $16(57.142 \%)$ female diabetic patients. Serum triglycerides $150-399 \mathrm{mg} / \mathrm{dl}$ was found to be in total $40(40 \%)$ diabetic patients, $28(38.888 \%)$ male diabetics and 12 (42.857\%) female diabetic patients as shown in table 4 .

In type 2 diabetic patients mean serum LDL-C levels were found to be $127.06 \mathrm{mg} / \mathrm{dl}$ in total diabetic patients. Serum LDL-C $<100 \mathrm{mg} / \mathrm{dl}$ was found to be in total 18 $(18 \%)$ diabetic patients, $12(16.666 \%)$ male diabetics and $6(21.428 \%)$ female diabetic patients. Serum LDL-C levels $100-129 \mathrm{mg} / \mathrm{dl}$ was found to be in total 31 (31\%) diabetic patients, $22(30.555 \%)$ male diabetics and $9(32.148 \%)$ female diabetic patients. Serum LDL-C levels $>130 \mathrm{mg} / \mathrm{dl}$ was found to be in total $51(51 \%)$ diabetic patients, 38 $(52.777 \%)$ male diabetics and $13(46.428 \%)$ female diabetic patients as shown in table 5 .

In male type 2 diabetic patients serum HDL-C level $>$ $35 \mathrm{mg} / \mathrm{dl}$ was found to be in $>59(81.944 \%)$ patients and HDL-C level $<35 \mathrm{mg} / \mathrm{dl}$ was found to be in 13 $(18.055 \%)$ patients. In female diabetic patients serum HDL-C level $>45 \mathrm{mg} / \mathrm{dl}$ was found to be in $8(28.571 \%)$ patients and HDL-C level $<45 \mathrm{mg} / \mathrm{dl}$ in 20 (71.42) patients as shown in table 6 .

\section{DISCUSSION}

The present cross sectional study entitled "EVALUATION OF DYSLIPIDEMIA IN TYPE 2 DIABETIC PATIENT" was carried out at medicine department of L.N. Medical college and associated J.K. Hospital, Bhopal (M.P.). Type 2 diabetes accounts for more than $90 \%$ of all cases of

\begin{tabular}{lccc} 
Table 3: Lipid profile in type 2 & diabetic patients \\
\hline Lipid Profile & $\begin{array}{c}\text { Total } \\
\text { patients }\end{array}$ & $\begin{array}{c}\text { Male } \\
\text { patients }\end{array}$ & $\begin{array}{c}\text { Female } \\
\text { patients }\end{array}$ \\
\hline Serum cholesterol $(\mathrm{mg} / \mathrm{dl})$ & 202.4 & 201.6 & 203.2 \\
TG $(\mathrm{mg} / \mathrm{dl})$ & 152.02 & 137.45 & 166.60 \\
HDL-c $(\mathrm{mg} / \mathrm{dl})$ & 42.86 & 43.40 & 42.32 \\
LDL-c $(\mathrm{mg} / \mathrm{dl})$ & 127.06 & 127.30 & 126.64 \\
\hline
\end{tabular}

\begin{tabular}{lccc}
$\begin{array}{l}\text { Table 4: Serum triglycerides levels in type } 2 \\
\text { diabetic patients }\end{array}$ & \multicolumn{3}{l}{ Male } \\
\hline $\begin{array}{l}\text { Serum triglycerides } \\
\text { (mg/dl) }\end{array}$ & $\begin{array}{c}\text { Total } \\
\text { patients }\end{array}$ & $\begin{array}{c}\text { Female } \\
\text { patients } \\
\text { patients }\end{array}$ \\
\hline$<150$ & 60 & $44(61.111)$ & $16(57.142)$ \\
$150-399$ & 40 & $28(38.888)$ & $12(42.857)$ \\
$>400$ & 0 & - & - \\
\hline
\end{tabular}

\begin{tabular}{lccc}
\multicolumn{4}{l}{ Table 5: LDL-C levels in type 2 Diabetic patients } \\
\hline $\begin{array}{l}\text { LDL-C levels } \\
\text { (mg/dl) }\end{array}$ & $\begin{array}{c}\text { Total } \\
\text { patients }\end{array}$ & $\begin{array}{c}\text { Male } \\
\text { patients (\%) }\end{array}$ & $\begin{array}{c}\text { Female } \\
\text { patients (\%) }\end{array}$ \\
\hline$<100$ & 18 & $12(16.666)$ & $6(21.428)$ \\
$100-129$ & 31 & $22(30.555)$ & $9(32.148)$ \\
$>130$ & 51 & $38(52.777)$ & $13(46.428)$ \\
\hline
\end{tabular}

\begin{tabular}{lccc}
\multicolumn{2}{c}{ Table 6: Serum HDL-C in type 2 Diabetic patients } \\
\hline \multicolumn{3}{c}{ Male patients } & \multicolumn{3}{c}{ Female patients } \\
\hline$>35(\mathrm{mg} / \mathrm{dl})$ & $<35(\mathrm{mg} / \mathrm{dl})$ & $>45(\mathrm{mg} / \mathrm{dl})$ & $<45(\mathrm{mg} / \mathrm{dl})$ \\
$59(81.944 \%)$ & $13(18.055 \%)$ & $8(28.571 \%)$ & $20(71.42)$ \\
\hline
\end{tabular}

diabetes in most countries and hence the major burden is due to its rising prevalence. ${ }^{17}$ The most important risk factor for these complications in diabetes is dyslipidemia. The present study was designed to evaluate the pattern of dyslipidemia in our study population.

The pattern of dyslipidemia in our study showed significantly higher level of serum cholesterol, serum triglycerides, LDL-C and low level of HDL-C in female diabetic group. There was no significant difference in lipid profile pattern in male and female diabetic patients except lower levels of HDL-C in female diabetic patients. Data from the Paris Prospective Study ${ }^{18}$ and the UKPDS shows that triglycerides in diabetic patients are higher than in the general population. ${ }^{19}$

In our study triglycerides level were also significantly higher in diabetics as compared to non-diabetic group. In our study serum cholesterol and LDL-C was found to be significantly higher in type 2 diabetic patients which differs from earlier study which states that mean levels of total cholesterol and LDL-C in those with type 2 diabetes may not differ significantly from those in non-diabetic subjects. ${ }^{20}$ In our study in HDL-C levels have been found to be low in women than in men which is in concordance with earlier studies. ${ }^{21}$ 


\section{CONCLUSION}

Our present study concludes that there was significantly higher levels of serum cholesterol, serum LDL-C level, serum triglyceride was found in type 2 diabetic patients, while serum HDL-C level was found to be significantly low in female diabetics otherwise there was no significant difference in lipid profile pattern was found in between male and female diabetic patients.

In conclusion this study has shown that dyslipidemia is highly prevalent amongst type 2 diabetic patients. This combined dyslipidemia, put them to increased risk of cardiovascular, cerebrovascular and peripheral arterial diseases morbidity and mortality. Efforts should therefore be intensified in the area of glycemic control, lipid lowering and lifestyle modifications among others to reduce the risk of morbidity and mortality in diabetic patients. Indeed the very high prevalence of dyslipidemia among diabetic subjects irrespective of duration of DM makes a case for early commencement of lipid lowering therapy even in the absence of biochemically proven dyslipidemia.

\section{IMPLICATIONS}

1. It will be helpful in understanding the prevalence and pattern of dyslipidemia in type 2 diabetes mellitus patients and also helpful in framing new policies and strategies to overcome it.

2. To initiate levels of prevention at the earliest possible stage and this is an important tool to prevent atherosclerosis and its consequences.

\section{ACKNOWLEDGEMENT}

We would like to cordially thank to all the patients for participating in this study and to the department of Medicine and Biochemistry of L. N. Medical College \& J. K. Hospital \& Research Center, Bhopal (M.P.), India for supporting this study and college authority for allowing to conduct the study.

\section{REFERENCES}

1. American Diabetes Association. Diagnosis and classification of diabetes Mellitus. Diabetes Care 2005; 28(1): 537-544.
2. Stookey DJ, Pieper FC, Cohen JH. Hypertonic hyperglycemia progresses to diabetes faster than normotonic hyperglycemia. Eur J Epidemiol 2004; 19:935-944.

3. Kasai T, Miyauchi K, Kajimoto K, Kubota N, Kurata T and Daida H. Influence of diabetes on>10 years outcomes after percutaneous coronary intervention. Heart Vessels 2008; 23:149-154.

4. Ramachandran A, Snehalatha C. Current scenario of diabetes in India. J Diabetes 2009; 1(1):18-28.

5. Frier B, Yang $P$, Taylor WA. Diabetes, aging and physical activity. Eur Rev Aging Phys Act 2006; 3:63-73.

6. Devrajani BR, Shah SZ, Soomro A and Devrajani T. Type 2 diabetes mellitus: A risk factor for Helicobacter pylori infection: A hospital based case-control study. Int. J. Diabetes Dev. Ctries 2010; 30(1): 22-26.

7. Chattanda SP, Mgonda YM. Diabetic dyslipidemia among diabetic patients attending specialized clinics in Dar es Salaam. Tanzania Med. J. 2008; 23(1): 08-11.

8. Ballantyne CM, Grundy SM, Oberman A. Hyperlipidemia: Diagnostic and therapeutic perspectives. J Clin Endocrinol Metab2000;85:208997.

9. Grundy P. Cardiovascular diseases remain nation's leading cause of death. J Am Med Assoc 1992; 267:3358

10. Coronary heart disease mortality trends among whites and blacks Appalachia and United States, 1980-1993MMWR Morb Mortal Wkly Rep 1998; 47:100512.

11. Garg A, Grundy SM. Management of dyslipidemia in NIDDM. Diabetes Care1990;13:153.

12. O'Brien T, Nguyen TT, Zimmerman BR. Hyperlipidemia and diabetes mellitus. Mayo Clin Proc 1998;73:969.

13. Goldberg IJ. Clinical review 124: Diabetic Dyslipidemia: Causes and Consequences. J Clin Endocrinol Metabol 2001; 86:965-971.

14. Hennes MM, O'Shaughnessy IM, Kelly TM. Insulin-resistant lipolysis in abdominally obese hypertensive individuals. Hypertension 1996; 28:120-126.

15. Barker DJP, Hales CN, Fall C. Type 2 diabetes mellitus, hypertension and hyperlipidaemia (syndrome $\mathrm{X}$ ): relation to reduced fetal growth. Diabetologia 1998; 36: 62-67.

16. Despres JP. Health consequences of visceral obesity. Ann Med 2001; 33: 534-541.

17. Ambady R, and Chamukuttan S. Early diagnosis and prevention of diabetes in developing countries. Rev Endocr Metab Disord 2008;9:193-201.

18. Toth PP. The "good cholesterol" high-density lipoprotein. Circulation 2005; 111:e89 e91.

19. Meilling GE. Clin Chem 1979; 22:1581. Cited by Varley's Practical Clinical Biochemistry $6^{\text {th }}$ Ed; Oxford, Heinemann Medical books. 1988;326-32.

20. U.K. Prospective Diabetes Study 27. Plasma lipids and lipoproteins at diagnosis of NIDDM by age and sex. Diabetes Care 1997; 20: 1683-1687.

21. Walden CE, Knopp RH, Wahl PW, Beach KW, Strandness E. Sex differences in the effect of diabetes mellitus on lipoprotein triglyceride and cholesterol concentrations. N Engl J Med 1984;11(15):953-959. 